\title{
LITERATURA E HISTORIA: O EXEMPLO DE VICTOR HUGO
}

\author{
Maria Teresa de Freitas
}

Dizem às vezes brincando que um francês que quer estudar as formas de governo, encontrará todos os exemplos possíveis estudando apenas a História de seu país, tantas foram as variaçōes que ele sofreu. A isso, poder-se-ia acrescentar: alguém que queira conhecer a História da França no século XIX, não precisa muito além de conhecer a vida e a obra de Victor Hugo.

E certo que tudo pode ser História: História de vidas, História da Literatura, História demográfica, História política, História social, História até das mentalidades, valorizada recentemente pelas grandes transformações por. que passou a História no início do século $\mathrm{XX}$, e cujas relações com a Literatura são de particular importância. Mas, no caso de Victor Hugo, pode-se dizer que tudo é mais História. Isso porque a história de sua vida e de sua obra é, ao mesmo tempo, a História das revoluções - e das evoluções - políticas, sociais e literárias da França no século XIX, a tal ponto que é impossivel referir-se a essa História sem pronunciar o seu nome.

Sua vida: foi, ao lado de Lamartine e de Chateaubriand, dos poucos poetas românticos que efetivamente participaram dos movimentos políticos da época, chegando até a ocupar cargos de uma certa importância no cenário político. Sua obra: apesar dos excessos românticos, da fertilíssima imaginação e do subjetivismo ostensivo, seus escritos, nos mais variados gêneros, poucas vezes deixaram de levar em conta, de uma forma ou de outra, acontecimentos históricos e implicações sociais; como talvez nenhuma outra, essa obra reflete a evolução das idéias literárias, políticas e morais do século todo. Vida e obra tornam-se assim inseparáveis sob a égide da História.

A participação de Victor Hugo na História, porém, se deu quase exclusivamente através da palavra, otal ou escrita. Nada mais natural: para um poeta, para um escritor, a palavra pode ser um

Língua e Literatura, (15), 1986. 
meio de ação. E ela o foi, nas mãos de $\mathrm{V}$ Hugo, com as mais diversas finalidades. Muitos foram, aliás, os que criticaram duramente sua "maleabilidade" política, que se adaptava aos diferentes governos que se sucediam na França após o Império de Napoleão I: poeta oficial das sucessivas monarquias - a dos Bourbons e a dos Orléans -, partidário depois até de um "império liberal", bonapartista que era, terminaria sua vida servindo a República que tanto hesitara em aceitar; a tal ponto que, quando enfim resolveu aderir a essa forma de governo, os jornais apontavam as contradições de um homem que iniciara sua carreira literária com "odes bourbonianas", e sua vida política como membro da "Câmara dos Pares" da monarquia de Louis-Philippe I. Há porém quem o justifique: numa época em que a República apenas nascia na França, confusões políticas se multiplicavam, diferentes regimes se sucediam, e tanto sangue se derramava em nome das mais diversas ideologias, não seria de se estranhar que tanto tempo tivesse sido necessário ao poeta para fundar com coesão suas convicções; sua incoerência política teria sido simplesmente a incoerência política do próprio século; sua carreira literária teria sido apenas perturbada por todas as paixões, como o foi também o panorama literário da época. Há enfim aqueles que o defendem com vigor: as sucessivas mutações representariam, na verdade, uma evolução na sua busca cada vez maior de liberalismo, já que não apoiou - e nem mesmo suportou, forçando-se ao exílio - a única mudança verdadeiramente autoritária, o Segundo Império, estando sempre a favor da liberdade e contra a tirania - o que bem reflete sua obra, que vai do mais puro conservadorismo aos mais republicanos anseios.

Victor Hugo: visconde, oficial da Légion d'honneur sob duas diferentes monarquias, "par" da França durante a monarquia constitucional de Louis-Philippe, representante do povo na II República, símbolo vivo do fim do autoritarismo e da definitiva instalação da República na França. Autor de um número sem fim de poemas, de peças de teatro de grande sucesso, de eloqüentes discursos para os mais diversos fins, de longos e intrincados romances que figuram entre os mais vendidos na França, na época. Qual teria sido a verdadeira mola motora a impulsionar uma vida tão intensa e uma obra tão fecunda? Uma ambição desmedida, em busca sempre de uma certa forma de poder? Uma versatilidade confusa porém privilegiada, que foi apenas o reflexo de uma época, uma de suas mais eloqüentes expressões? Ou anseios verdadeiramente humanitários, de poeta denunciador das opressões e das misérias sociais, defensor de todas as liberdades? 
Se a resposta se mostra difícil, as evidências são reveladoras. "Contra o sucesso não há argumento", diz um ditado popular. E sucesso é o que não faltou a esse homem, desde a imensa vendagem de seus livros, até às delirantes aclamações populares, sobretudo na volta do exílio, passando, entre outras, pelas gloriosas comemorações populares de seus oitenta anos, e culminando com a apoteose de seu enterro. E, se esse sucesso foi, como todos sabem, devido em grande parte ao fato de ter sido ele o "pai" do Romantismo na França, não se pode esquecer que a História exerceu grande influência em sua obra, comprometendo-a sobremaneira com a atualidade da época, a tal ponto que se pode dizer que ele foi também, de certa forma, o precursor da Literatura engajada, que iria conhecer seus anos áureos um século mais tarde em seu país.

"Fui jogado aos 16 anos no mundo literário por paixões políticas", escreverá Hugo em 1829, no prefácio de uma de suas peças, Marion de Lorme. Com efeito: o início de sua carreira literária, subvencionado por Louis XVIII, já possui cunho político: as duas odes de 1818, "Les Vierges du Verdun" e "Le retablissement de la statue d'Henri IV", exprimem o mais puro conservadorismo de um monarquista católico; e, no prefácio das Odes et poésies diverses, de 1822 , o poeta declara que, na base de sua obra, se encontram duas intençōes concomitantes, a literatura e a política; o que ele busca é a "renovação da ode histórica, emprestando-lhe uma idéia fundamental qualquer, apoiada sobre acontecimentos contemporâneos" Não seria essa a mesma idéia fundamental que estaria na base da futura literatura de combate na França? Sem dúvida: algum tempo depois, o jornal La Muse Française - órgão oficial do grupo dos Românticos - publica uma corajosa ode censurando o governo pela queda ministerial de Chateaubriand; assinado: Victor Hugo.

Morre Louis XVIII; nasce "Les Funérailles de Louis XVIII"; a História e a poesia. Sobe ao trono Charles $\mathrm{X}$, irmão do antigo monarca, que se apressa em declarar V Hugo oficial da Légion d'Honneur e em convidá-lo para a sagração; a resposta é imediata: Ode sur le sacre de Charles $X$; o acontecimento histórico e sua expressão poética.

Entretanto, a decepção causada pela desgraça que atingira Chateaubriand aumenta, na medida em que o regime de Charles $\mathrm{X}$ vai se tornando, aos poucos, autoritário; e a figura carismática de $\mathrm{Na}$ poleão, herança talvez do pai, combatente e servidor do Império, começa a obcecá-lo e a servir-lhe de inspiração literária: Odes et Ballades, 1826, e Ode à la Colonne, 1827. exaltam a glória do 
Império, e revelam em seu autor o bonapartista escondido ou reprimido até então. Essa rebeliāo política, cantada em versos, se faz acompanhar de uma rebeliāo literária, representada no palco: Cromwell, também em 1827, vai, como dirá Vigny, "cobrir de rugas" todas as tragédias da época. Primeiro drama propriamente romântico, seu célebre prefácio é considerado um marco histórico na $\mathbf{L i}$ teratura, e faz de seu autor o chefe de uma nova escola. Verdadeiro manifesto anti-clássico, esse prefácio propõe a ruptura com as regras literárias estabelecidas no passado, e inovaçōes totalmente revolucionárias, que vão desde a mistura dos gêneros até à valorização do povo na Literatura, passando pela reivindicação de integrar o grotesco na obra de arte:

\begin{abstract}
" la muse moderne .. sentira que tout dans la création n'est pas humainement beau, que le laid y existe à côté du beau, le difforme près du gracieux le grotesque au revers du sublime, le mal avec le bien. l'ombre avec la lumière (...) Tout ce qui existe dans le monde, dans l'histoire, dans la vie, dans l'homme, tout doit et peut s'y réfléchir, mais sous la baguette magique de l'art"' (1).
\end{abstract}

Trata-se, como se vê, de um grande apelo à liberdade em Literatura . Apenas em Literatura? E por acaso existem duas liberdades distintas, uma literária, outra política?

Para V Hugo, não: dois anos depois, uma nova peça, Marion de Lorme, será proibida pela censura de Charles X - certamente porque atacava indiretamente a monarquia absoluta, já anunciada antes por Richelieu, que se preparava nos bastidores do poder: a História temendo a influência da Literatura. No mesmo ano, 1829, numa época em que nem se cogitava colocar em questão a pena de morte, Hugo publica Le dernier jour d'un condamné, romance-tese, que não é outra coisa senão um comovente discurso de defesa pela abolição da pena de morte; o autor elimina propositadamente a intriga romanesca propriamente dita, e confere à personagem uma psicologia o mais geral possível, para tentar retratar os tormentos morais e físicos de todo condenado à morte. Eloquência e lirismo juntam-se aí com vistas ao resultado a ser obtido, que não é, em hipótese alguma, apenas despertar a curiosidade e o interesse do leitor, mas sobretudo comovê-lo para convencê-lo. Era a primeira de suas batalhas por essa causa; como arma de combate, o romance.

(1) - "Préface" de Cromwell. Paris, Larousse, 1949. págs. 25 e 45. 
No ano seguinte, um drama onírico, liberto de todas as regras e imposições do Classicismo, consegue enfim transpor as "sagradas" portas clássicas da Comédie Française; era Hernani, de Victor Hugo. E, ao mesmo tempo em que vencia assim a tradição clássica literária, a peça se mostrava também profundamente histórica: a célebre batalha travada no palco, naquele mês de fevereiro, parecia anunciar uma outra, travada nas ruas, cinco meses depois; atrás das barricadas parisienses, que se ergueram em julho de 1830 para derrubar Charles $\mathrm{X}$, cujas medidas autoritárias prenunciavam a instalação da monarquia absoluta, podia-se reconhecer muitos dos rostos avistados na platéia da Comédie Française na noite de estréia de Hernani. A revolução literária havia pressentido - e de certa forma preparado - a revolução política. Em suas notas, Hugo escrevera: "Precisamos da coisa República e da palavra Monarquia": a revolução de Julho levaria a França à monarquia constitucional de Louis-Philippe, que deveria conduzir gradativamente o país de volta à República. Aos vencedores, um hino: Ode à la Jeune France; a poesia cantando a História.

Todavia, em vez de esperanças, são decepções que sobrevêm; uma insatisfação geral do povo vai provocar sangrentos motins e violentas repressōes. Dessa insatisfação, Hugo tentará ser não apenas o porta-voz - o "eco sonoro" como ele próprio se intitulara numa das poesias de Feuilles d'Automne, em 1831 -, mas muito mais: o Poeta - aquele que, segundo ele, é investido de uma missão a cumprir, qual seja, a de levar a verdade ao povo, instrui-lo, alertá-lo para o pergio, e, acima de tudo, defendê-lo, conforme precisara nos prefácios de suas peças:

"Le drame a une mission nationale, une mission sociale, une mission humaine (.. ) Le théâtre doit à la foule une philosophie, aux idées une formule, à chacun un conseil, à tous une loi (...) Le théâtre est un lieu d'enseignement" (2).

Como não reconhecer aí a linguagem do escritor engajado, aquele que se propõe como objetivo lutar por uma causa? São os problemas sociais que o preocupam; e, acima de tudo, uma certeza: a de que a questão social deve ter prioridade sobre a questão política. Doravante, será esse seu programa literário, que abrange a poesia, o teatro e o romance, e que o levará mais tarde às assembléias políticas. Assim, o teatro será para ele — não só, mas também -

(2) - Citado por A. Tolédano, Victor Hugo (coll. Les grands orateurs républicains) Monaco, Hemera, 1949, pág. 15. 
uma espécie de tribuna política e social, que antecede a verdadeira tribuna onde subirá em breve: Le roi s'amuse, 1832, severo contra a monarquia, é precedida de manifestações contra o rei e a aristocracia; por ordem do monarca "liberal", a peça será suspensa sine die, após a primeira apresentação: novamente, a História temendo a Literatura. Seus demais dramas da década serão todos de natureza social e reivindicatória, culminando com Ruy Blas, em 1838, cujo tema filosófico é o povo aspirando atingir as camadas mais elevadas da sociedade. Também sua obra em prosa revela, cada vez mais, tendências humanitárias. Em 1831, é o grande Notre-Dame de Paris, imenso afresco da Paris do século XV. que situa a intriga melodramática num contexto histórico preciso, e apresenta um quadro sólido dos hábitos e costumes da Idade Média; no prefácio de 1832, I Hugo exorta o leitcr a:

". démêler sous le roman autre chose que le roman, et à
suivre le système de l'historien et le but de l'artiste à travers
la création du poète" (3);

o sistema do historiador: restituir a época em questão; o objetivo do artista: denunciar as injustiças e as misérias sociais. A História e a Literatura. Claude Gueux, 1834, é seu segundo combate pela abolição da pena de morte; baseado num fato verídico, constitui um exemplo concreto da tese geral do anterior; é a amplificação poética do discurso de defesa apresentado pelo próprio acusado.

No entanto, apesar dessas idéias progressistas de cunho democrático, a quimera do império liberal sob o signo de Napoleão não o abandona. Frustada sua tentativa de ação - a morte de Napoleão II no exílio inutiliza os contatos mantidos com vistas a preparar sua possível volta ao trono da França -, revela, através de suas poesias, as ilusões que sobreviveram às esperanças perdidas: alguns poemas de Les Chants du Crépuscule, em 1835, e o Retour de l' Empereur, em 1840, por exemplo, prosseguem a tarefa de espalhar a lenda napoleônica e seu antigo sonho com uma espécie de "bonapartismo social" capaz de conciliar sua admiração por Napoleão e suas aspirações igualitárias; apesar de suas tendências democráticas, mantém a idéia de uma elite dirigente.

Contudo, a Literatura não lhe basta; cada mais se vê atraído pela vida pública, e se julga dotado para fazê-la progredir: se os políticos não conseguem resolver a crise, não caberia aos intelectuais

(3) - P. Berret, Victor Hugo. Paris, Garnier Frères, 1939, pág. 335. 
substitui-los? Com o casamento do príncipe herdeiro, o novo duque de Orleans, surge para o poeta a oportunidade de realizar seus anseios: a noiva, a princesa alemã Helena de Macklembourg, é amante fervorosa de Literatura, e, em particular, do romantismo francês; seu poeta preferido não é outro senão. Victor Hugo. Abrem-se assim para ele as portas do Palácio Real; inicia-se assim para ele a escalada em direção a um cargo político oficial. Em 1841, quando é afinal eleito membro da severa Academia Francesa de Letras, a família real adentra solenemente, pela primeira vez, as portas do Instituto, para ouvir o discurso de posse; e, perante toda a elite literária e política da época, V Hugo faz, para espanto de todos, uma profissão de fé exclusivamente política e social, verdadeira "candidatura a uma câmara", ou "programa ministerial", como chegou a comentar um jornal da época. Nesse discurso, ele oferece sua colaboração à dinastia dos Orleans, como guia espiritual: é a missão do poeta.

Aqui começa extra-oficialmente sua carreira política: num espaço de quarenta anos, ele irá, sempre por meio de imagens literárias, tentar criar sucessivamente um rei, uma regente, um imperador, e por fim, uma república européia. Oficialmente porém, continua a ser "apenas" um escritor; mas sempre um escritor preocupado com a História e com os problemas de sua época. Le Rhin, 1842, onde cotejam poesia, história e pitoresco, foi redigido após três viagens aos países do Reno, quando então se documentou minuciosamente sobre a História da Alemanha, colheu lendas, observou paisagens, anotou detalhes; "Conclusion du Rhin" artigo que se seguiu à obra e que ele próprio considera um "frio e grave" estudo de História, aborda questões de política estrangeira; Les Burgraves, do ano seguinte, reconstitui os burgos do Reno numa época brutal, sendo, ao mesmo tempo, pretexto para uma profissão de fé sobre a unidade dos povos.

Em 1845, consegue afinal o tão sonhado cargo político: é nomeado para a Câmara dos Pares - Alta Câmara Real, espécie de Senado da época, onde se misturavam a antiga aristocracia e a nova feudalidade burguesa - para grande decepção dos republicanos, que há quinze anos aguardavam sua adesão. No entanto, inicia-se aí a fase menos produtiva da sua vida literária, que durará até 1852 , início de seu longo exílio. Sabe-se que já preparava nessa época os gigantescos Les Contemplations e Les Misérables; mas é fato também que a ação política o absorvia amplamente. Por outro lado, seus discursos na Câmara, onde tentava aplicar seus ideais políticos e sociais, constituiam verdadeiras páginas literárias: apesar de reivindicatórios, eram feitos de variações líricas em torno de temas políticos, 
e, além disso, elaborados a partir de processos dramáticos. E o que explica a eloquiência com que, em todos esses anos de tribuna, defenderá questões como: a insurreição dos camponeses na Polônia austríaca, a anistia do irmão de Napoleão - no que contribuiu para a autorização da volta à França de todos os membros da família Bonaparte, condenados ao exílio -, a liberalidade do Papa Pio IX, a liberdade da Imprensa e do Ensino, a abolição da pena de morte, o incentivo às letras e às artes, o sufrágio universal: "poesias políticas recitadas na tribuna", como dirá $\mathrm{P}$ de Lacretelle, um de seus mais ferozes críticos (4). A Literatura na História. Além disso, a familiaridade com a família real vai lhe servir como fonte de um novo gênero de atividade literária: tendo adquirido o hábito de anotar num diário encontros, conversas, fatos quotidianos, publica em 1847 Choses vues, fragmentos de um testemunho histórico, onde são descritos hábitos e costumes da época; por trás das descrições, estarão constantemente presentes as preocupações com a questão social; assim por exemplo, ao sair de uma festa, o poeta observará o olhar do povo sobre os convidados, e prenunciará:

"Quand la foule regarde les riches avec ces yeux-là, ce ne sont pas de simples pensées; ce sont des événements (. .). L'ancienne Europe s'écroule. ; demain est sombre et les riches sont en question dans ce siècle comme les nobles au siècle dernier" (5).

E a revolução proletária que ele prevê: a História na Literatura.

Entre 1848 e 1851, Victor Hugo sofrerá a grande metamorfose política de sua vida, que marcará indelevelmente a imensa obra que ainda lhe resta a escrever De monarquista transformado em bonapartista e depois em orleanista fervoroso (com a abdicação de LouisPhilippe I, por ocasião da Revolução de fevereiro de 1848, lutará pela regência da duquesa de Orleans, já que o duque morrera e seu filho era menor), o poeta irá afinal aderir à República - "cette majestueuse forme sociale. ., que nos pères ont vue grande et terrible dans le passé, et que nous voulons tous voir grande et bienfaisante pour l'avenir" (6) -, primeiramente como representante

(4) - P de Lacretelle, Vie politique de Victor Hugo. Paris, Hachette, 1928, pág. 48 .

(5) - Cf. Alain Décaux, Victor Hugo. Libr. Académique Perrin, 1984, pág. 670 .

(6) - Citado por A. Tolédano, op. cit., pág. 19. 
da ala direita, por quem fora eleito para a Assembléia Constituinte, e depois enfim como aliado do então enfraquecido grupo dos socialistas. Cometera o grande erro político de apoiar a candidatura de Louis-Napoléon Bonaparte, sobrinho de Napoleão, à presidência da II República; para isso, contara com um precioso instrumento de combate, o jornal L'Evénement, que seus filhos fundaram e dirigiam sob sua orientação. Mais tarde, no exílio, ao escrever o romancereportagem que conta a história do golpe, Histoire d'un crime, $\mathrm{V}$ Hugo transcreverá as palavras veementes com as quais o príncipe o tranquilizara a respeito de suas intenções sobre o governo:

"Et que pourrais-je recommencer de Napoléon? Une seule chose. Un crime. La belle ambition! Pourquoi me supposer fou? (...) Mon nom, le nom de Bonaparte, sera sur deux pages de l'Histoire de France: dans la première, il y aura le crime et la gloire, dans la seconde, il y aura la probité et l'honneur" (7)

Não fora o único, entretanto, a se deixar enganar pelas aparências: junto ao seu, muitos outros nomes ilustres figuram entre as futuras vítimas do príncipe. Além disso, é bem possível que, na admiração constante que sua fértil imaginação nutria por Napoleão e pela epopéia imperial, V Hugo acariciasse ainda, secretamente, o eterno sonho do império liberal: eleito Louis-Napoléon, L'Evénement aconselhará o príncipe-presidente a ler o monólogo do personagem Carlos V, de Hernani, para tirar daí inspirações para seu programa de chefe de Estado; ora, nesse monólogo, o célebre personagem sonha: "Imperador, imperador, ser imperador!": a Literatura prenunciando a História. Democracia e liberdade dentro da aura da glória, era tudo o que podiam desejar os arroubos românticos do poeta, e - por que não dizê-lo? - sua ambição política; talvez almejasse tornar-se um daqueles frequientes personagens de seus dramas que, todo-poderosos, governavam através de príncipes fracos ou povos derrotados: o drama romântico transposto para a cena política. Todavia, ao se dar conta do erro em que incorrera, vai tentar repará-lo; começa então para ele uma árdua e desastrosa batalha na tribuna: tendo contra si a maioria de direita que o elegera, seus discursos serão, via de regra, ridicularizados, enquanto tenta, sem nenhum sucesso, continuar a defender as liberdades que gradativamente vão sendo extintas pelo governo. Muitos anos depois, o personagem Gwinplaine, de L'Homme qui rit, o pobre desfigurado que, de miserável transforma-se subitamente em nobre, cairá inúmeras vezes no

(7) - Paris, Eugène Fasquelle, Première Partie. 
ridículo ao tentar desesperadamente explicar aos de sua casta aquilo que eles ignoram na essência: a miséria. A experiência política se transformando en matéria de romance.

$\mathrm{Na}$ última dessas batalhas, usará como principal arma a eloquência: diante da proposta de revisão da Constituição, cujo objetivo velado era permitir a reeleição de Louis-Napoléon, ele brada na tribuna sua fatal previsão:

"Il ne faut pas que la France soit prise par surprise et se trouve un beau matin avoir un empereur sans savoir pourquoi! ( ) Quoi! parce que nous avons eu Napoléon de Grand, il faut que nous ayons Napoléon le Petit?" (8)

E essa grande imagem antitética encontrada no calor da revolta, iria estruturar grande parte de sua obra literária no exílio; mais tarde, ela marcaria para sempre a figura de Napoleão III diante da História.

Naquele momento, porém, a luta será inglória. Embora recusada a proposta de revisão, o príncipe-presidente não hesita diante da única solução que lhe resta: o golpe de estado. E ao poeta, o exílio. Vinte anos, quase; vinte anos de luta, no entanto! Sua faculdade de reconstruir sobre ruinas era prodigiosa: logo, ele retomaria $o$ combate, com a arma que melhor sabia manejar:

"Louis-Napoléon a dix mille canons et cinq cent mille soldats; l'écrivain a sa plume et son encrier (. .) Encrier contre canon. L'encrier brisera les canons" (9).

Seriam, como ele mesmo o disse, longos anos de exílio a serviço da República, numa guerra aberta e violenta contra o novo imperador da França, por intermédio sobretudo de sua obra literária. A Literatura como forma de combate. Ao chegar à Bélgica, primeira parada do exílio, declara que tem um dever a cumprir: o de escrever a História imediata da França; "ator, testemunha, juiz" ele se julga o "historiador completo" E assim, os quatro fatídicos dias de dezembro de 1851 se transformarão nas mais de quinhentas páginas da Histoire d'un crime, no famoso panfleto Napoléon-le-Petit, e na maior parte

\footnotetext{
(8) - Cf. A. Tolédano, op. cit., págs. 148-149.

(9) - Citado por J. -B. Barrère, Hugo. Paris, Hatier, 1952, pág. 121.
} 
da não menos famosa coletânea de poemas satíricos que foi Les Châtiments. Sua veia literária, há tanto tempo estagnada ou reprimida pela História, retoma, alimentando-se da mesma História, seu curso com toda força e entusiasmo daquela imaginação prodigiosa.

Apesar do escritor ter se fundamentado não apenas em suas próprias lembranças, mas também em documentos recebidos de Paris, e em relatos de companheiros de exílio, não se pode considerar propriamente históricas essas obras. Por um lado, os relatos eram de natureza pessoal e unilateral. Por outro lado - e este é o aspecto mais importante da questão - o autor se coloca muito mais na posição de "testemunha-vingadora", como queria Chateaubriand, do que na de historiador; no início de Napoléon-le-Petit ele declara categoricamente seus objetivos:
"se dresser éternellement debout devant le traître, son serment à la main (.. ); saisir l'abominable parjure couronné, sinon avec la main de la loi, du moins avec les tenailles de la vérité, et faire rougir au feu de l'histoire toutes les lettres de son serment pour les lui imprimer sur la face" (10).

Ele bem o disse: “em pé”; é a postura do combatente, e não a do historiador. Assim, Histoire d'un crime, espécie de reportagem romanceada detalhada do golpe de Estado de 2 de dezembro, é na verdade um relato romântico e dramático, onde a parcialidade e as paixões imperam, onde a imaginação privilegiada do exilado aumenta tumultuosamente os fatos e faz jorrar através das palavras toda sua cólera, o que exclui qualquer possibilidade de senso crítico; com seu dom épico, $\mathrm{V}$ Hugo trata o assunto não apenas como um acontecimento histórico, mas também como um confronto entre o Bem e o Mal. Do mesmo modo, Napoléon-le-Petit, panfleto sob forma de drama de um só movimento, se insere nessa crise de furiosa indignação do poeta; embora seja considerado como uma obra-prima da retórica de protesto, tudo aqui é levado a um paroxismo que se sobrepõe à verdade; retoma, além disso, sua idéia da superioridade do poeta sobre os fatos e da conviç̧ão de que ele tem uma missão sagrada a cumprir:

"Eh bien, ce maître, ce triomphateur, ce vainqueur, ce dictateur, cet empereur, ce tout-puissant, un homme seul, errant, dépouillé, ruiné, terrassé, proscrit, se lève devant lui et l'atta-

(10) - Id. Ibid. 
que (...) L'écrivain n'est rien, c'est un grain de poussière, c'est une ombre, c'est un exilé sans asile, c'est un vagabond sans passe-port (sic), mais il a à ses côtés et combattant avec lui deux puissances, le Droit, qui est invincible, et la Vérité, qui est immortelle" (11).

A História desperta nele toda a eloquiência literária; sua inspiração é desmedida. Mas, por trás dos excessos, a profecia:

\begin{abstract}
"Vous ne voyez ... pas que le Deux-décembre n'est qu'une immense illusion, une pause, un temps d'arrêt, une sorte de toile de manoeuvre derrière laquelle Dieu, ce machiniste merveilleux, prépare et construit le dernier acte, l'acte suprême et triomphal de la Révolution Française!" (12):
\end{abstract}

com efeito, o Segundo Império seria finalmente o último entrave à instalação definitiva da República na França.

Em Les Châtiments, concluido em Jersey, em 1853, o acontecimento iria nos proporcionar versos admiráveis; sua cólera levada ao paroxismo perante o plebiscito que, um ano após o golpe, faria efetivamente de Louis-Napoléon Bonaparte o Napoleão III, segundo imperador dos franceses, paradoxalmente se organiza do ponto de vista artístico, e adquire maior força, ao combinar fins estéticos com fins polêmicos. Divulgada clandestinamente na França, essa obra lhe valeria a posição de chefe espiritual da oposição republicana; ele encarna aí um mito que será acariciado durante vinte anos em suas obras, o do justiceiro, com todo vigor de seu temperamento e sem nenhuma pretensa objetividade: "não há poesia lírica sem o $e u$ ", dissera Hugo um dia; e seu eu ali está com toda sua força: cada verso é uma imprecação, uma investida, um ataque. Sua experiência real das barricadas - de que tomara parte - deixara-lhe as imagens trágicas que se traduzem nos versos, produzindo os mais intensos sentimentos de piedade, admiração, entusiasmo e horror - elementos típicos do drama trágico. E a História transformada em tragédia, com o objetivo de despertar no leitor toda sua emoção estética, e tentar assim agir sobre sua sensibilidade. Como não perceber aí o germe da Literatura de combate do século XX francês?

(11) - in F. Bonte, Le chevalier de la paix. Paris, Ed. Sociales, 1952, pág. 40 .

(12) - Cf. A. Décaux, op. cit., págs. 797-798. 
Em Guernesey, terceiro e último abrigo no exílio, para onde se retirou em fins de $1855, \mathrm{~V}$ Hugo conseguirá recuperar definitivamente toda sua glória literária. Além dos poemas de Les Contemplations, ele conclui também aí seu grande romance social, Les Misérables, que ele define como "a história misturada ao drama, o século, um amplo espelho refletindo o gênero humano num determinado dia de sua imensa vida" (13). Epopéia dos humildes, onde vemos um ex-condenado e uma prostituta darem lições de moral e de virtude a uma sociedade corrompida, não faltam aí os grandes afrescos históricos, para os quais o escritor se documentou rigorosamente, não apenas em livros, mas também com viagens, pesquisas e enquetes: a batalha de Waterloo, a insurreição de 1832, os principais movimentos populares do século. Além disso, conforme demonstraram alguns críticos, apesar da imaginação sem limites, há uma preocupação sistemática com a autenticidade dos dados objetivos e dos meios sociais apresentados no romance, que dramatiza visões precisas: por trás da grandiosidade épica, que transfigura o real, revela-se a História, que ele faz poeticamente reviver. "E o Evangelho do século XIX. Todos o compreenderam", dirá um jornalista famoso na época (14): como não perceber aí, a despeito da exacerbação romântica, a importância do conteúdo sócio-histórico do romance? A Literatura fornecendo vasta matéria à História social e política.

E também em Guernesey que $\mathrm{V}$ Hugo redige La légende des siècles, essa imensa epopéia humana, gigantesca História da Civilização contada em versos, que vai desde a gênese e a decadência do Império Romano até aos Tempos Modernos, passando pelo Islam, pelo ciclo heróico cristão, pelos tronos do Oriente, pela Itália medieval, Inquisição, Renascimento, e, é óbvio, pela epopéia napoleônica. Mas, apesar da documentação considerável utilizada pelo poeta, os fatos históricos são aqui interpretados e transfigurados pela imaginação. É, como ele próprio dirá, a História ouvida através das portas da lenda. Ora, não são as lendas o alimento maior do imaginário coletivo? E o que é, então, a transformação da História em lenda, senão sua garantia de sobrevivência e de repercussão entre os povos através dos tempos?

Essa imaginação ilimitada, nutrida porém sempre pela História, apresenta agora uma nítida evolução em sua idéias de base: o contato com proscritos de outras nacionalidades fornece-lhe uma visão mais geral da política européia, e inspira-lhe novos ideais sobre o

(13) - Id. ibid., pág. 893.

(14) - Cf. J. -B. Barrère, op. cit. pág. 191. 
futuro do continente; começa a tomar corpo o grande sonho dos Estados Unidos da Europa, pedra de base de uma futura República Universal, sem fronteiras, fundada sobre os princípios gerais de igualdade, liberdade, progresso moral e material, para a união de todos os povos: é a sua imensa utopia da paz universal. Esse ideal, V Hugo irá defender, no exílio, perante todos os públicos que se lhe oferecerão: em Bruxelas, diante da imprensa parisiense; em Lausanne, aos membros do Congresso da Paz e da Liberdade - do qual ocupa a Presidência honorária; nas cartas públicas, onde defende a liberdade dos povos oprimidos por governos invasores; nos manifestos contra as crueldades das expedições de Napoleão III na Criméia e no México; na proclamação dos direitos das raças negras; nos protestos constantes contra a pena de morte; nos pedidos insistentes de anistia a todos os perseguidos. Contudo, é sobretudo sua obra literária que vai continuar a lhe servir de tribuna: Les Travailleurs de la Mer, 1866, é um hino em homenagem à grandeza humana diante do impossível e do infinito, romance invadido por teorias sociais; L'Homme qui rit, 1869, é uma verdadeira denúncia, um grito de revolta, contra a soberba da sociedade aristocrática da época, elevado por Gwinplaine que, ao tentar inutilmente comover uma assembléia de pares em favor dos miseráveis, torna-se a encarnação da maldade que os homens podem deliberadamente infringir a um semelhante; e, nas peças que compõem o volume Le Théâtre en Liberté, é visível a preocupação com a condição social e com a união dos povos.

E nesse momento de grande importância da História da França, quando Napoleão III decreta a guerra contra a Prússia, o poder da Literatura se mostra com todo vigor: V Hugo recusara-se, pela segunda vez, a voltar à França, apesar da anistia agora irrestrita, percebendo a eficiência da arma que escolhera, mesmo manejada à distância; com a total recuperação literária - suas obras conhecem um sucesso que nenhum outro escritor conseguira em todo o século - também sua imagem pessoal se recupera: todos prestam atenção a essa voz que vem do Oceano. E a Literatura influenciará a História: o texto clandestino de Les Châtiments circula pelos colégios e universidades, e repercute fortemente entre aqueles que, em 1852, eram jovens demais para entendê-lo; a imagem que se espalha de Napoleão III é aquela que Hugo imprimiu nesse texto. E óbvio que seria exagerado dizer que essa repercussão teria causado a queda do imperador; é inegável, no entanto, que ela influenciou os ânimos, já exaltados e há muito decepcionados com a forma autoritária com que o Império vinha sendo conduzido. Se o tinteiro não venceu o canhão, ele ao menos ajudou a vencê-lo. 
A seus filhos, na iminência de abrir um novo jornal em Paris, Hugo escreve:

"Attendre. Faire des oeuvres. En somme cela vaut mieux que de faire des journaux" (15).

E mesmo esse jornal, Le Rappel, que afinal foi aberto, deve sua indiscutível influência nos acontecimentos que apressaram a queda do Império à popularidade do ilustre nome do exilado que o apadrinhava.

Com a queda do Império, após a derrota de Napoleão III, V Hugo, embora sendo contra qualquer guerra, vai defender seu país invadido; e é então que ocorre sua maior glória em vida: a apoteótica volta do exílio, em setembro de 1870 . Em Paris, uma multidão delirante o acalma, aos gritos de "viva", ao som de "La Marseillaise" e aos versos de Les Châtiments. Considerado a encarnação da República universal, devido quase que exclusivamente ao sucesso de sua obra literária, ele resumia todas as esperanças do povo e do novo governo. Nas semanas que se seguem, sua casa se torna uma espécie de sede paralela à do governo provisório: todos ali vêm para consultá-lo. Nessa hora, se o quisesse, teria provavelmente chegado à frente do governo; no entanto, o poder não mais o tenta; afinal, não mostrara ele a todos que o poeta serve melhor sua pátria cantando-a do que governando-a? Assim, faz reeditar suas obras, repete as antigas exortações à luta, promove leituras públicas de seus versos: o lucro obtido é doado para a compra de canhões, dos quais um foi denominado "Victor Hugo" e outro "Les Châtiments" A Literatura como meio - desta vez concreto - de combate.

Após o armistício, a Commune, essa sangrenta insurreição de Paris contra o governo. Victor Hugo, que se demitira da Assembléia logo depois de ter sido eleito, publica versos contra os excessos cometido dos dois lados. Novamente, a História e a poesia. Outro exílio voluntário: para quem sonhara com a união de todos os povos, é insuportável a visão do seu próprio se dilacerando internamente. Outra luta através da poesia: os versos engajados de L'Année Terrible, em 1872, relatam a História imediata - a derrota do imperador, a ocupação da França pelos prussianos e os sangrentos episódios da Commune - ao mesmo tempo em que denunciam os atos de violência, onde quer que sejam praticados; trata-se de uma espécie

(15) - Cf. A. Décaux, op. cit., pág. 918. 
de diário em versos de um ano de guerra e de insurreição. Reportagem e protesto em forma de poesia.

Seu povo dividido, os políticos se engalfinhando, seus ideais afogados em sangue, decepciona-se com a História presente, para se refugiar na passada: Quatre-vingt-treize, de 1874, representa a concretização de um de seus grandes sonhos: um romance sobre a Revolução Francesa. Este será seu romance histórico por excelência, onde as lembranças de relatos de infância vão se juntar a pesquisas e viagens documentais. Tentando dar uma visão imparcial de um episódio da grande revolução, o da guerra de Vendée, na Bretanha, e, concomitantemente, restituir aspectos da vida quotidiana da época, Hugo documentou-se amplamente, não apenas sobre os acontecimentos, mas também sobre os hábitos e costumes. Observa-se aí todo seu poder de evocação na arte de ressuscitar fatos, pessoas e lugares. No fundo porém, não se libera do engajamento com a atualidade: o romance é também a transposição cronológica de situaçōes semelhantes: 1793 foi, exatamente como 1871, o ano em que guerras externas se acumularam com agitações internas de grande porte na França. A Literatura mostrando a História que se repete.

A ameaça de um novo golpe de Estado mediante a mudança de governo, leva-o de volta à França em 1876. Eleito senador pela região do Sena, pronuncia, em junho de 1877, seu mais sábio discurso, contra a dissolução da Câmara, onde prevê a eventualidade do golpe. Em vão: a dissolução é aprovada, e com ela, um novo perigo para a República se anuncia. V Hugo volta então a usar aquela que se revelou ser sua melhor arma: faz publicar Histoire d'un crime, inédito até então; na primeira página, um aviso: "Este livro é mais do que atual: ele é urgente"; para prevenir um crime, a história de outro. A Literatura contra a História. E mais uma vez, a Literatura influenciará a História: a repercussão é tamanha que o governo tentará - inutilmente - interditar o livro; os republicanos conseguem a maioria na Câmara, e o presidente se demite. Este último combate ganho valerá a Hugo sua perenidade: passará para a posteridade como o Patriarca da República.

Em 1789, transformará em novos versos seus insistentes apelos pela anistia geral: La Pitié Suprême; o que os discursos na tribuna não haviam conseguido, a poesia conseguirá: logo, a anistia será concedida. E, há cem anos atrás, 415 das 418 vozes da Câmara e do Senado franceses decidem conceder as honras de Chefe de Estado a um homem que não o fora; assim, os funerais de Victor Hugo 
são celebrados com grandiosidade inusitada, e sua última marcha triunfal, do Arco do Triunfo ao Panteão, é apopeótica.

Romântica por excelência, os grandes defeitos de sua obra teriam sido, segundo dizem, a imaginação exacerbada, a irrealidade quase caricatural de seus personagens, o exagero dos efeitos dramáticos; como explicar, então, que esses seres imaginários penetraram tão profundamente no inconsciente coletivo que sobrevivem ainda hoje mos quatro cantos do mundo? Se o melodrama era inverossíf mel, se o romantismo se exacerbava, se o idealismo era utópico, como é possível que alguns de seus romances tenham até mesmo servido de apoio a estudos de História social, como por exemplo o minucioso Classes laborieuses et classes dangereuses à Paris, de Louis Chevalier? Transformando seus personagens em seres lendários, as chances de atingir o povo eram bem maiores; revestindo suas idéias de idealismo e de utopia, os meios de influenciar a massa eram mais eficazes, já que agiam sobre sua sensibilidade. Sua consciência privilegiada de criador conseguiu captar aquelas "pulsações do sangue subterrâneo" que nutre as artérias da História - como dirá Malraux -, além da realidade aparente, e transmitir assim o jogo de forças escondidas que estava latente no inconsciente coletivo de um povo, e que iria portanto mover a História.

Idealista, fez de sua obra também uma arma; e sua luta não foi vã. Visionário, foi por vezes também um profeta. Lutou pela democracia na França: ele próprio viu - e viveu - a definitiva instalação da República em seu país. Imaginou os Estados Unidos da Europa: seus netos talvez tenham podido ver a criação da Comunidade Econômica Européia. Sonhou com a união de todos os povos: quem sabe um dia alguém possa ver realizar-se também esse, o maior e mais utópico de seus sonhos. 